\title{
EARLY BYZANTINE PEACOCK BROOCHES IN THE SOUTHERN CAUCASUS IN THE EARLY MEDIEVAL PERIOD
}

\author{
ANNA VLADIMIROVNA MASTYKOVA
}

\author{
Archaeological Heritage Protection Department of the Institute of Archaeology \\ of the Russian Academy of Sciences, Moscow, Russia \\ amastykova@mail.ru
}

\begin{abstract}
This paper discusses Early Byzantine clasps in the form of peacock, which occurred in modern Abkhazia and Kartli. These brooches date from the sixth and seventh centuries and meet with parallels among synchronous mediaeval antiquities. Peacock brooches discovered in the Southern Caucasus were imported directly from Byzantium. These finds indicate connections of the population of the Southern Caucasus and the Byzantine Empire.

Keywords: Southern Caucasus and Byzantium, brooches, Byzantine influence
\end{abstract}

This paper discusses Early Byzantine clasps in the form of peacock, which occurred in the Southern Caucasus (Fig. 1-4). Small zoomorphic brooches were well known in the Caucasus in the Great Migration Period (from the last third of the fourth to the second third of the sixth century AD). ${ }^{1}$ These brooches in the Caucasus belong to the big group of small bird-shaped brooches which existed in Europe from the mid-fifth to mid-seventh century. They belong to female attire and were widespread in Western Europe, in the Middle Danube area, on the Balkans, and in the Caucasus. ${ }^{2}$ Besides, there were big bird-shaped brooches, finery and trappings with encrustation, featuring another morphology and popular among the Eastern Germanic peoples in Spain and Italy, ${ }^{3}$ as well as along the Danube and in the Carpathians, particularly in the Pietroasele treasure and in the "princely" grave of Apahida II. ${ }^{4}$ All the listed types of brooches reflect international female fashion from the fifth to mid-seventh century and, obviously, originate from common Late Roman prototypes. Actually, the image of bird of prey, specifically of eagle, often occurred among the Roman symbols, which were imitated by barbarians. ${ }^{5}$

However, the bird-shaped brooches include several outstanding pieces featuring not a feathered predator but unaggressive peacock (Fig. 5. 1-3). These brooches depict a bird with crested head, elongated body, and long oval tail. In the Southern Caucasus, I know only three finds of brooches of the type: two pieces originate from the territory of modern Abkhazia, from cemeteries of Tsibilium-2 and Shapka-Yustinianov Kholm-3, and the third piece comes from the territory of Kartli, from Samtavro (Fig. 4).

The excavation on the cemetery of Tsibilium-2, at the footstep of the famous fort of Tsebelda, in the northeastern area of the Tsebelda valley (Gulripsh area), which formed a part of ancient Apsilia, uncovered inhumation grave 282, with the burial of a teenager girl ${ }^{6}$ whose head was oriented to the west (Fig. 1.1). The grave contained a

${ }^{1}$ MaстЫKова 2016а; Мастыкова 2016b; MastyкоVA 2016; МАСТЫКОВА 2017.

${ }^{2}$ THIRY 1939; WERnER 1961, Taf. 41-43; LEGOUX-PÉRINVALLET 2009, № 235-251.
${ }^{3}$ Bierbrauer 1975, 121, 122; Ebel-ZePERZAUer 2000, 29-31; vON RuMMEL 2007, 331-337; vON RUMMEL 2012, 51-66.

${ }^{4}$ HARHOIU 1998, 92.

${ }^{5}$ GREENE 1987; vON RUMmel 2012.

${ }^{6}$ Gender and age has been determined by Yu. N. Voronov. 


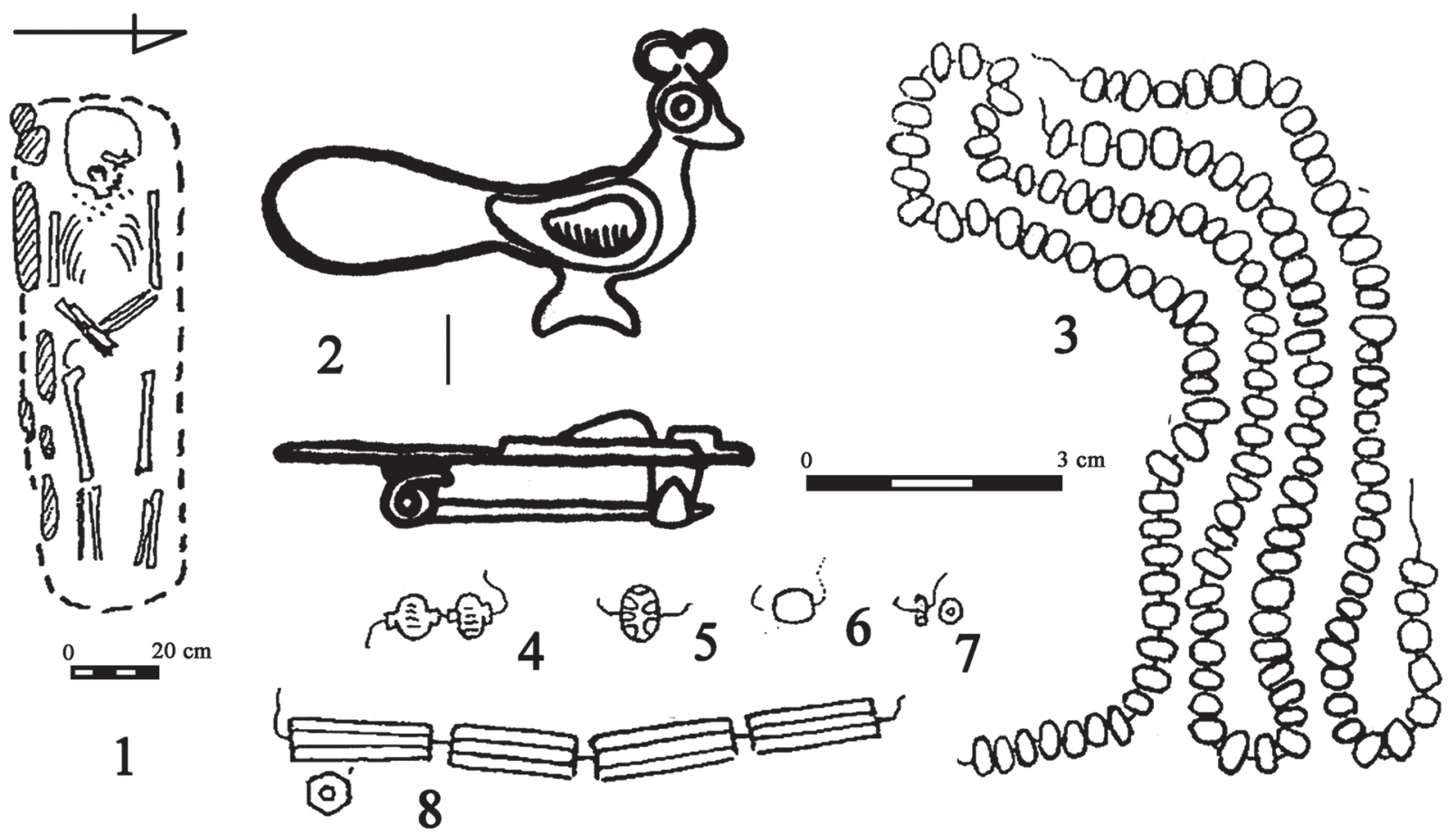

Fig. 1. Grave 282 in the cemetery of Tsibilium-2 (according to Воронов 2003, рис. 133.7-15)

brooch featuring peacock with elongated body, long oval tail, crested head, and the wing decorated with oval green glass inset (Fig. 1.2). There is no information on the location of this brooch in the grave. The burial was accompanied with numerous beads of various types made of glass, carnelian, and amber (Fig. 1.3-8). ${ }^{7}$ Taking the grave goods into account, there are reasons to date this grave to Stage IV/10-11 of the Abkhazian timeline, corresponding to AD 530/550-640/670. ${ }^{8}$

The second peacock brooch, which form is absolutely the same as that of the previous artefact, was excavated from grave 4 in the cemetery of Shapka-Yustinianov Kholm-3, ${ }^{9}$ in the south-western area of the Tsebelda valley (Gulripsh area) (Fig. 2). This grave contained an inhumation, with the head oriented to the north (Fig. 2.1). On the chest of the skeleton there was a bronze brooch depicting peacock with elongated body, elongated oval tail, and crested head; its tail and wing were decorated with oval insets of light blue glass. Overall size of the brooch is $4.5 \mathrm{~cm}^{10}$ (Fig. 2.2.A,E) ${ }^{11}$ This grave also contained grave goods typical of female burials: silver and bronze bow fibulae with wide back-plate and crossbar, glass, carnelian, and amber beads, bronze bracelets and pendant earrings, bronze toilet set and fragments of a needle-case including bronze needles, bronze bell, iron knife, and ceramic vessels (Fig. 2.3-22). The excavators have dated this burial to the third quarter of the seventh century. ${ }^{12}$ Olga Gei and Igor Bazhan have related this grave to Period 8 of their chronology, corresponding to AD $425-450 .{ }^{13}$ However, cross-like brooches of the latest variant (Fg. 2.15-18) and pendant earrings (Fig. 2.3-5) suggest that the most probable chronology of this assemblage is AD 530/550-640/670, i. e. Stage IV/10-11 of the Abkhzian timeline. ${ }^{14}$

The third find is a bird-shaped brooch from grave 578 in the year 1946 from the cemetery of Samtavro in Mzkheta in Kartli in the ancient Iberia (Fig. 3). ${ }^{15}$ General outline of the bird's body and the crest on its head allow me to relate this brooch to the group of peacock brooches, though in contrast to Abkhazian finds its tail is sub-tra-

\footnotetext{
${ }^{7}$ Воронов et al. 1982, 25, рис. 29.18; ВоРонов 2006, pиc. 29.107; VORONOV 2007, 66, Fig. 133.8.

${ }^{8}$ KAZANSKI-MASTYKOVA 2007, 59.

${ }^{9}$ Воронов-Юшин 1973, 184, рис. 13. The find resides in the State Museum of Abkhazia, in the city of Sukhum.

${ }^{10} \mathrm{I}$ am indebted to Valentin Aleksandrovich Niushkov for this information.
}

\footnotetext{
${ }^{11}$ Воронов-Юшин 1973, 184, рис. 13.21; ВоРонов 2010 70, рис. 21.6.

${ }^{12}$ ВоРОНов-Юшин 1973, 184.

${ }^{13}$ ГЕЙ-БАЖАН 1997, 26, 27, табл. 29.21.

${ }^{14}$ Cf.: KaZAnski-Mastykova 2007, Pl. 27.3,4,6.

${ }^{15}$ АПХАЗАВА 1979, 117, табл. IX.2.
} 

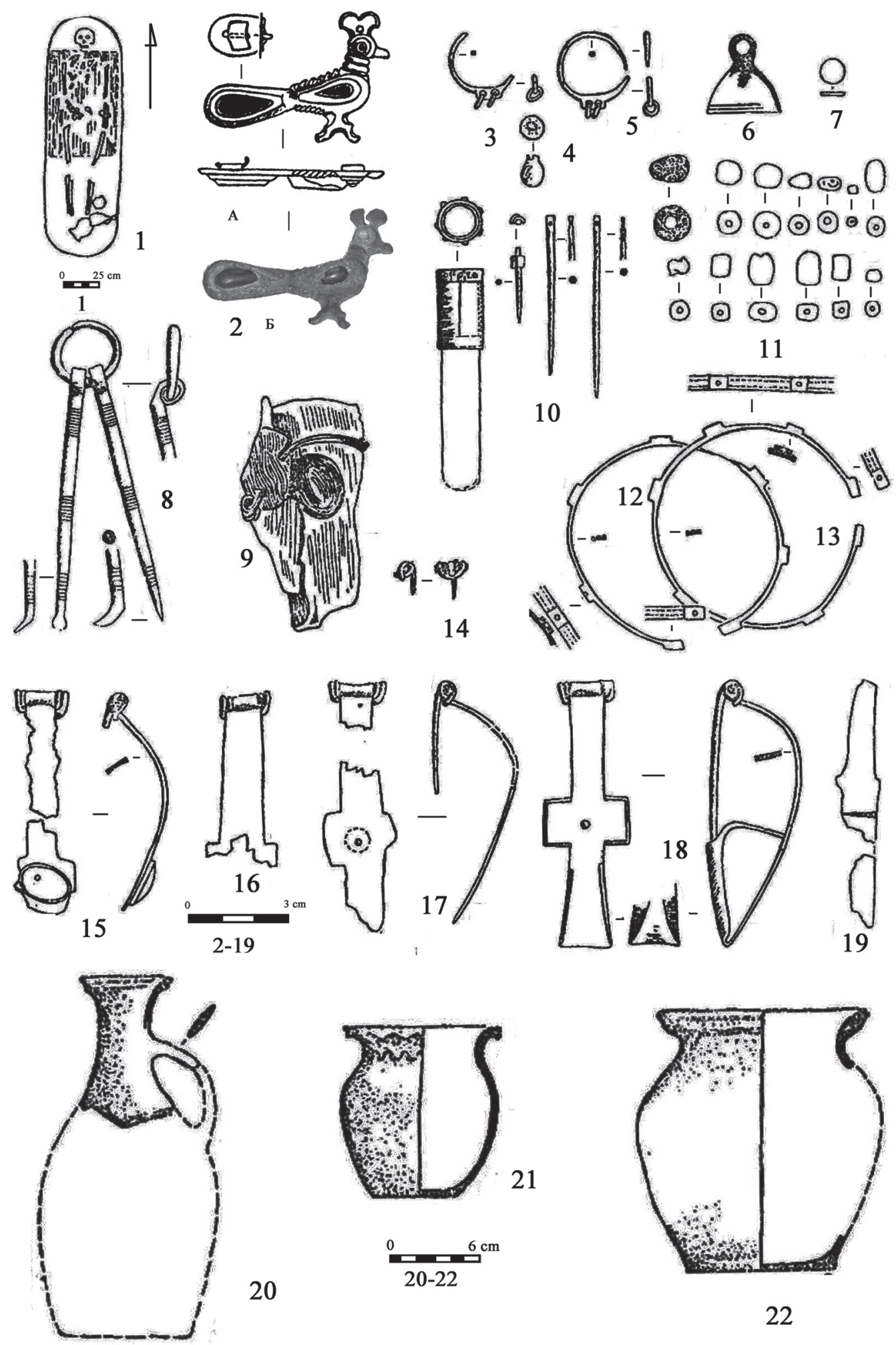

Fig. 2. Grave 4 in the cemetery of Shapka-Yustinianov Kholm-3 (according to Воронов-Юшин 1973, рис. 13) 

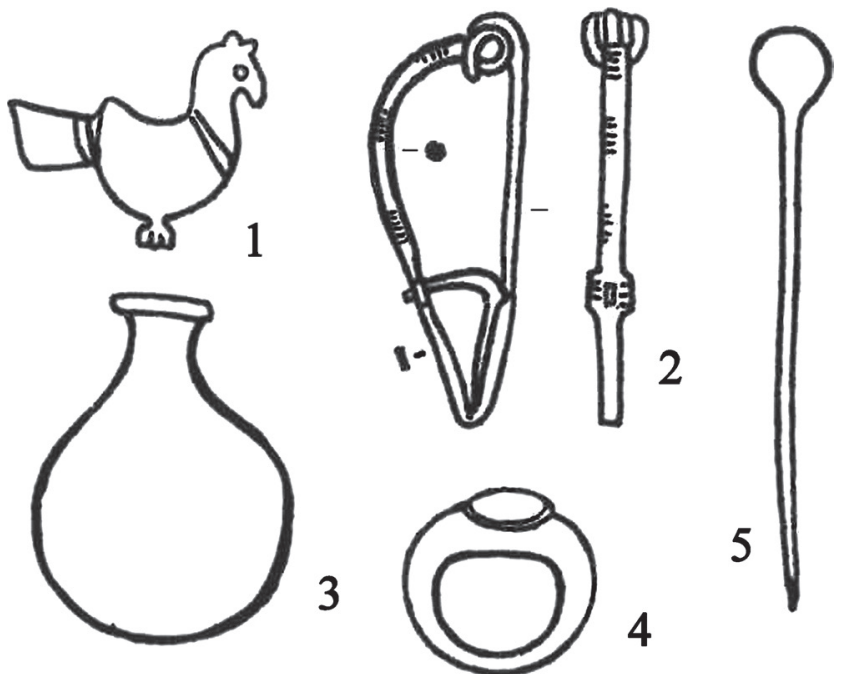

Fig. 3. Grave 578 of the year 1946 in the cemetery of Samtavro (according to АПХАзАвА 1979, табл. IX.1-5)

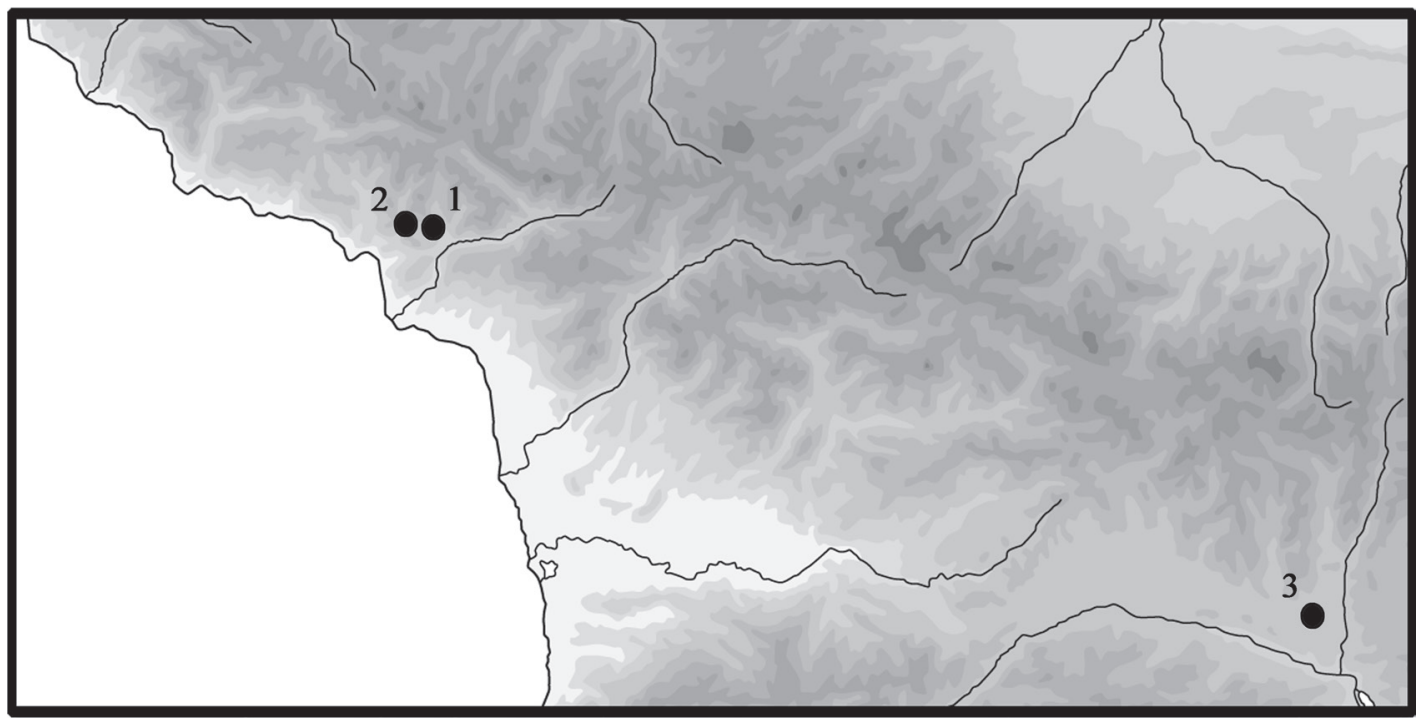

Fig. 4. Distribution map of peacock brooches in the Transcaucasia. 1: Tsebelda; 2: Shapka; 3: Samtavro

pezium, and it does not have elongated body nor inset decoration (Fig. 3.1). From the cross-shaped brooch of an early form (Fig. 3.2 $)^{16}$ there are reasons to relate this burial to the finds from Stage III/5-8 in the Abkhazian timeline, corresponding to $\mathrm{AD} 380 / 400-440 / 450 .{ }^{17}$

The style of these three brooches greatly differs from other bird-like ornaments from the Central Caucasus, so they "fall out" the general group of Caucasian finds. Yurii Voronov was the first to underline that these bird-like brooches were Late Roman/Byzantine and met with parallels in the Eastern Mediterranean area. ${ }^{18}$ Actually peacock is one of the favourite motifs of the Early Byzantine decorative art, where it symbolised eternity and revival, and also emperor's power. Images of peacock often occurred on metal artefacts of other types (Fig. 6.1-4; Fig. 7.1-3). ${ }^{19}$

\footnotetext{
${ }^{16}$ АпХАЗАВА 1979, табл. IX.1.

${ }^{17}$ KAZANSKI-MASTYKova 2007, 57, Pl. 24.

${ }^{18}$ Воронов-Юшин 1973, 188; Воронов 2010, 70.
}

${ }^{19}$ See e. g.: Ross 1962, Pl. XXVIII, N 41; Ross 1965, Pl. LXXVII, N 164; BÉNAZETH 1992, 235, N $^{\circ}$ E27248; ЗАЛЕCCKAЯ 2006 , 142, № 276; DEPPERT-LiPPITZ 2008, Abb. 1; Al OMARi 2008, Abb. 3. 

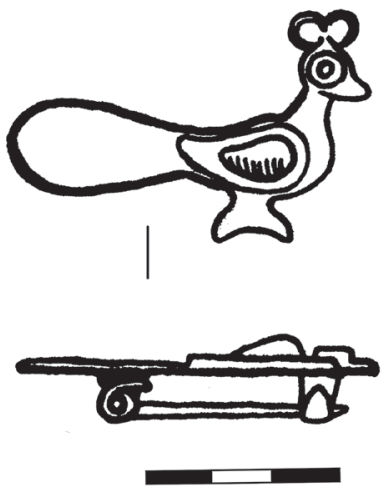

1
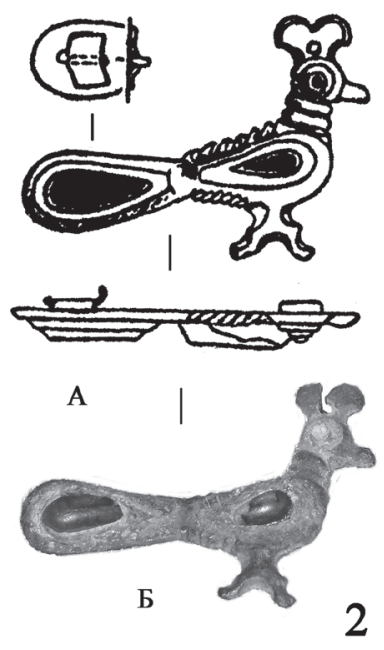

2
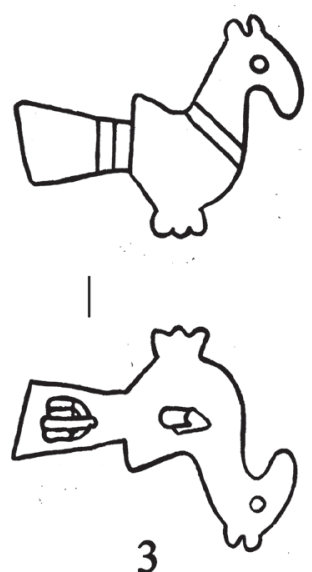

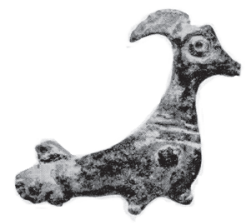

4

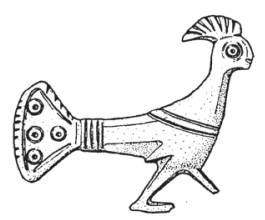

5

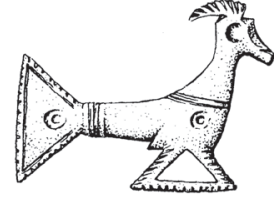

6

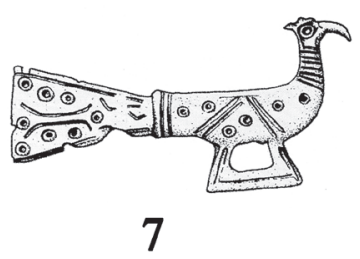

7

Fig. 5. Peacock brooches in the Transcaucasia (1-3) and their Mediterranean parallels (4-7). 1: Tsibilium-2, grave 282 (according to Voronov 2007, Fig. 133,8); 2: Shapka-Yustinianov Kholm-3, grave 4 (according to - A: Воронов-Юшин 1973. рис. 13.21; B: author's photo, the collection of the Abkhazian State Museum); 3: Samtavro, grave 578 of the year 1946 (according to AпХАЗАBA 1979, табл. IX.2); 4: Baron Johannes von Diergardt's Collection at the Roman-Germanic Museum, Köln (according to WeRNER 1961, Taf. 49.322);

5, 6: Invillino (according to MARTIN 1994, Abb. 162.4,5); 7: Villa Lagarina (according to BIERBRAUER 2008, Abb. 5.3)

Similar brooches are well known in the Mediterranean, particular in Italy, where they are considered typical Mediterranean (Romanian) pieces (Fig. 5.4-7). ${ }^{20}$ Most probable is Yurii Voronov's suggestion that peacock brooches in the Southern Caucasus were imported directly from Byzantium. In the Northern Caucasus, no peacock brooch has been found so far. It is interesting to note that in the Southern Caucasus a few finds of peacock brooches appeared in the areas (Iberia, Apsilia) that kept permanent and varied contacts with Byzantium (Fig. 4).

It should be mentioned that ornaments depicting peacocks came into the hands of barbarians who lived far away from Byzantine borders. As Anatolii Ambroz has shown once, ${ }^{21}$ zoomorphic images on brooches from the Martynovka treasure in the Dnieper area (Fig. 6.4 ${ }^{22}$ represent bird's heads. Martynovka brooches laid the foundation for a big series of anthropo- and zoomorphic brooches from the Dnieper area. ${ }^{23}$ This famous treasure originates from the forest-steppe area on the right bank of the Dnieper. ${ }^{24}$ It belonged to the Penkovka culture people, e. $g$. Slavic-speaking Antae, and dates most likely from the last third or the end of the sixth century. ${ }^{25}$

Translated from Russian by Nikita Khrapunov

${ }^{20}$ WERNER 1961, 54, Taf. 49.322; BIERBRAUER 1992, Abb. 1.5, 3.8, 14; Bierbrauer 2008, Abb. 4.3,4; Martin 1994, Abb. 162.4-6.

${ }^{21}$ АмБРОз 1993, 181.

${ }^{22}$ PeKarsKaja-Kidd 1994, Taf. 3, 4.

\footnotetext{
${ }^{23}$ For details see: Родинкова 2006а; Родинкова 2006 b.

${ }^{24}$ PeKarskaja-Kidd 1994.

${ }^{25}$ KAZANSKI 2013, 831-848.
} 

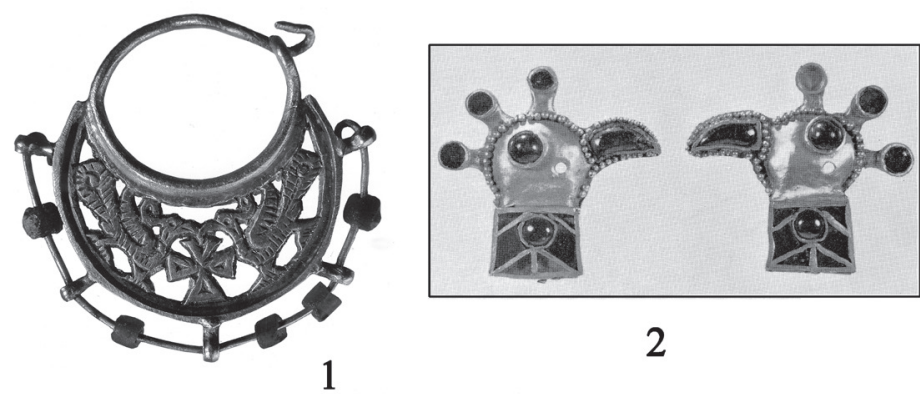

2
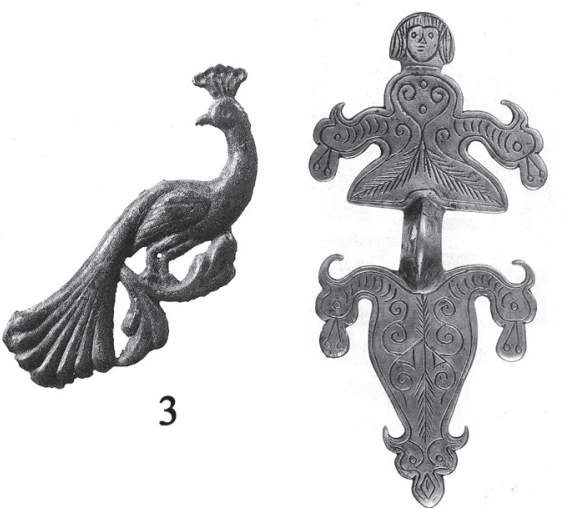

4

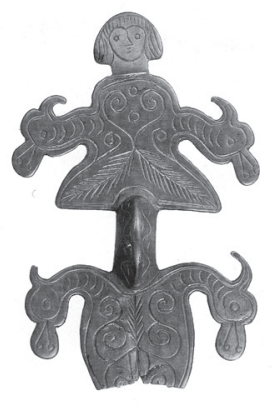

Fig. 6. Early Byzantine metal artefacts depicting peacock (1-3) and the barbarian imitations (4). 1: Syria (?) (according to DePPERT-LiPPITZ 2008, Abb. 1); 2: Hungary, Dumbarton Oaks (according to Ross 1965, Pl. LXXVII, N 164);

3: Upper Egypt, Louvre (according to BénAZETH 1992, 235, n E27248); 4: Martynovka (according to PeKARSKAJA-KidD 1994, Taf. 3,4)
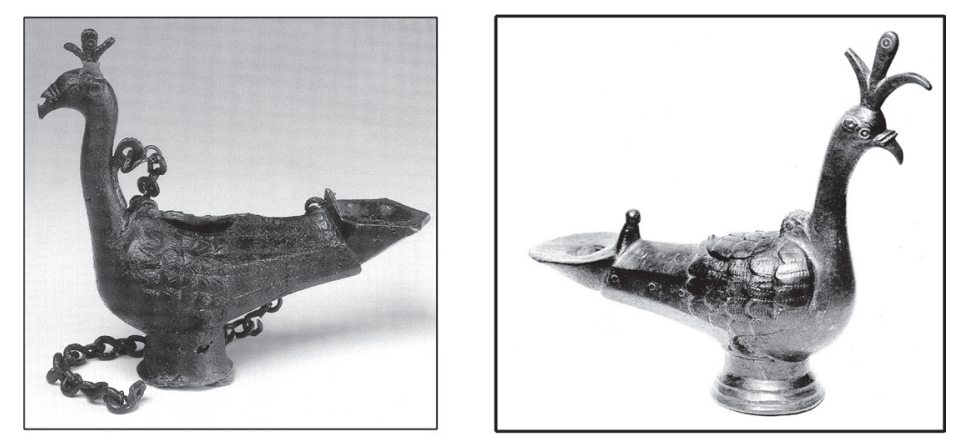

1

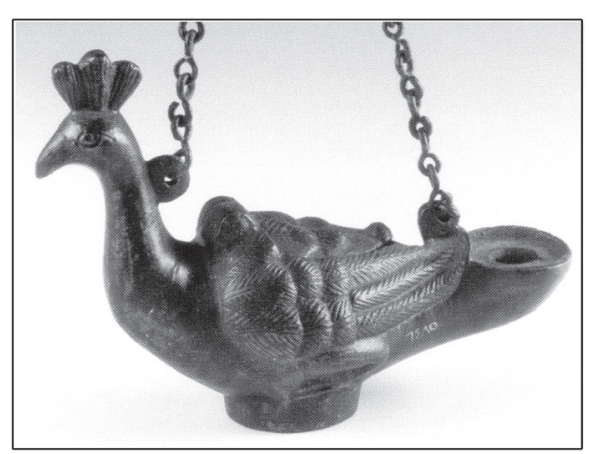

2

3

Fig. 7. Early Byzantine metal oil lamps depicting peacock. 1: Egypt, State Hermitage Museum (according to ЗАЛЕССКАЯ 2006, № 276);

2: Egypt, Dumbarton Oaks collection (according to Ross 1962, Pl. XXVIII, N 41); 3: Syria, National Museum, Damascus (according to Al OMARI 2008, Abb. 3) 


\section{REFERENCES}

AL OMARI 2008

BÉNAZEETH 1992 BIERBRAUER 1975 BIERBRAUER 1992

V. BIERBRAUER 2008

DEPPERT-LIPPITZ 2008

EBEL-ZEPERZAUER 2000

GREENE 1987

HARHOIU 1998

KAZANSKI 2013

KAZANSKI- MASTYKOVA 2007

LEGOUX-PÉRIN-VALLET2009

MARTIN 1994

MASTYKova 2016

PeKARSKAJA-KIDD 1994

Ross 1962

Ross 1965

VON RUMMEL 2007

VON RUMMEL 2012

THIRY 1939

VORONOV 2007

WERNER 1961

АмБРОз 1993

АпхАЗАВА 1979

ВоРОНОв 2006

ВоРОнов 2010

ВоРонов-Юшин 1973

Воронов et al. 1982
= H. Al OMARI: Byzantinische Lampen im Nationalmuseum von Damaskus. In: Die Kunst der frühen Christen in Syrien. Zeichen, Bilder und Symbole vom 4. bis 7. Jahrhundert. Hrsg.: M. Fansa, B. Bollmann. Mainz 2008, 120-123.

= D. BÉNAZEETH: L'art du métal au début de l'ère chrétienne. Paris 1992

= V. BIERBRAUER: Die ostgotischen Grab- und Schatzfunde in Italien. Spoleto 1975.

$=\mathrm{V}$. BIERBRAUER: Zwei romanische Bügelfibeltypeen des 6. und 7. Jahrhunderts im mittleren Alpenraum. Ein Beitrag zur Kontinuitäts- und Siedlungsgeschichte. In: Festschrift zum 50jährigen Bestelen des Instituts für Ur- und Frühgeschichte der Leopold-Franzens-Universität Innsbruck. Bonn 1992, 37-73.

= V. BIERBRAUER: «Alboin adduxit Langobardos in Italia». Langobarden nach der Einwanderergeneration: Verliert die Archäologie ihre Spuren im 7. Jahrhundert? In: Kulturwandel in Mitteleuropa. Langobarden - Awaren - Slawen. Hrsg.: J. Bemmann, M. Schmauder. Bonn 2008, 467-489.

= B. DePPERT-LipPITZ: Gold- und Silberschmiedekunst - Herstellungstechniken. In: Die Kunst der frühen Christen in Syrien. Zeichen, Bilder und Symbile vom 4. bis 7. Jahrhundert. Hrsg.: M. Fansa, B. Bollmann. Mainz 2008, 102-111.

= W. EBel-ZePERZAUER: Studien zur Archäologie der Westgoten vom 5.-7. Jh. n. Chr. Mainz am Rhein 2000.

= K. GREENE: Gothic material culture. In: Archaeology as Long-Term History. Ed.: I. Hodder. Cambridge 1987, 117-131.

= R. HARHOIU: Die frühe Völkerwanderungszeit in Rumänien. Bukarest 1998.

= M. KAZANSKI: The Middle Dnieper area in the seventh century: an archaeological survey. Travaux et Mémoires 17 (2013) 769-864.

= M. KAZANSKI-A. MASTYKova: Tsibilium: La nécropole apsile de Tsibilium (VIIe av. J.-C.-VIIe ap. J.-C.) (Abkhazie, Caucase). 2. : L'étude du site. BAR IntSer 1721. Oxford 2007.

$=$ R. LEGOUX-P. PÉRIN-F. VALLET: Chronologie normalisée du mobilier funéraire mérovingien entre Manche et Lorraine. Saint-Germain-en-Laye 2009.

= M. MARTIN: Fibel und Fibeltracht. Späte Völkerwanderungszeit und Merowingerzeit auf dem Kontinent. In: RGA 8/5-6. Berlin-New York 1994, 541-582.

$=$ A. Mastykova: Les fibules aviformes dans le Caucase du Nord et leurs parallèles mérovingiens. Bulletin de Liaison de l'Association Française d'Archéologie Mérovingienne 40 (2016) 20-25.

= L. V. PeKarskaJA-D. KIDD: Der Silberschatz on Martynovka (Ukraine) aus dem 6. und 7. Jahrhundert. Innsbruck 1994.

= M. C. Ross: Catalogue of the Byzantine and Early Medieval Antiquities in the Dumbarton Oaks Collection. 1.: Metalwork, Ceramics, Glass, Glyptics, Painting. Washington 1962.

= M. C. Ross: Catalogue of the Byzantine and Early Medieval Antiquities in the Dumbarton Oaks Collection. 2.: Jewellery, Enamels and Art of the Migration Period. Washington 1965.

= P. VON RuMMEL: Habitus barbarus. Kleidung und Repräsentation spätantiker Eliten im 4. und 5. Jahrhundert. Berlin-New York 2007.

= P. VON RUMMEL: L'Aquila Gotica. Sull'interpretazione di un simbolo. In: La Trasformazione del Mondo Romano e le Grandi Migrazioni. Nuovi popoli dall'Europa settentrionale e centro-orientale alle coste del Mediterraneo. Atti del Convegno internazionale di studi Cimitile-Santa Maria Capua Vetere, 16-17 giugno 2011. Ed.: C. Ebanista, M. Rotili. Cimitile 2012, 51-66.

= G. THIRY: Die Vogelfibeln der Germanischen Völkerwanderungszeit. Bonn 1939.

= You. Voronov: Tsibilium: La nécropole apsile de Tsibilium (VIIe s. av. J.-C.-VIIe s. ap. J.-C.) (Abkhazie, Caucase). 1.: Les fouilles de 1977-1986. BAR IntSer 1721. Oxford 2007.

= J. WERnER: Die Fibeln der Sammlung Diergardt (Völkerwanderungszeitlicher Schmuck). 1. Berlin 1961.

= А. К. АмБРоз: К происхождению днепровских антропо-зооморфных фибул. РоссАрх 1993/2, 179-184.

= Н. И. АПХАЗАвА: Материальная культура раннесредневековой Грузии (вопросы археологической хронологии по данным украшений). Тбилиси 1979 (на груз. яз.).

= Ю. Н. Воронов: Колхида в железном веке. In: Ю. Н. Воронов: Научные труды. 1. Сухум 2006 , 12-293.

= Ю. Н. Воронов: Тайна Цебельдинской долины. In: Ю. Н. Воронов: Научные труды. 3. Сухум 2010, 8-140

= Ю. Н. Воронов-В. А. Юшин: Новые памятники цебельдинской культуры в Абхазии. СА 1973/1, 171-191.

= Ю. Н. ВоРОНОВ-О. Х. БГАЖБА-Н. К. ШенКАО-В. А. ЛоГинов: Исследования в Цебельде. In: Археологические открытия 1980 года в Абхазии. Ред.: Г. К. Шамба. Тбилиси 1982, 21-26. 
ГЕЙ- БАЖАН 1997

ЗАЛЕССКАЯ 2006

Мастыкова 2016а

МАСТЫКовА 2016b

Мастыкова 2017

Родинкова 2006а

Родинкова 2006b
= О. А. ГЕЙ-И. А. БАЖАН: Хронология эпохи «Готских походов» (на территории Восточной Европы и Кавказа). Москва 1997.

= В. Н. ЗАЛЕССКАЯ: Памятники византийского прикладного искусства IV-VII веков. Каталог коллекции. Санкт-Петербург 2006.

= А. В. МАстыковА: Кавказские птицевидные фибулы-броши эпохи Великого переселения народов. In: Изучение и сохранение археологического наследий народов Кавказа. XXIX Крупновские Чтения. Материалы Международной научной конференции. Грозный, 18-21 апреля 2016 г. Отв. ред. : М. Х. Багаев, Х. М. Мамаев. Грозный 2016, 163-165.

= А. В. МАстыковА: Птицевидные фибулы эпохи Великого переселения народов на Кавказе и Северном Причерноморье: история изучения и вопрос происхождения. In: XVII Боспорские Чтения. Боспор Киммерийский и варварский мир в период античности и средневековья. Исследователи и исследования. Отв. ред. : В. Н. Зинько, Е. А. Зинько. Керчь 2016, 280-288.

= А. В. МАстыковА: О механизме распространения птицевидных фибул и подвесок у населения Центрального Кавказа в раннем средневековье. Stratum plus 2017/5, 259-288.

= В. Е. РодинковА: К вопросу о типологическом развитии антропозооморфных фибул (простые формы). РоссАрх 2006/3, 41-51.

= В. Е. РодинковА: К вопросу о типологическом развитии антропозооморфных фибул (сложные и двупластинчатые формы). РоссАрх 2006/4, 50-63. 